\title{
A RARE CASE OF ANGIOMYXOMA
}

Ashok Jain ${ }^{1}$, Anjali Dalai²

HOW TO CITE THIS ARTICLE:

Ashok Jain, Anjali Dalai. " A Rare Case of Angiomyxoma". Journal of Evolution of Medical and Dental Sciences 2014; Vol. 3, Issue 31, July 31; Page: 8642-8645, DOI: 10.14260/jemds/2014/3100

ABSTRACT: Angiomyxoma is a rare mesenchymal neoplasm. It mainly presents in female. It is generally a benign tumor and does not invade the neighboring tissues. It has a tendency to recur after surgical excision so it is termed as aggressive. The commonest site is labia majora.

KEYWORDS: Angiomyxoma, puberty, female, polypoidal growth.

INTRODUCTION: First described by Steeper and Rosai in 1983, angiomyxoma is a mesenchymal tumor found mainly in the pelvis and perineum. There is a strong female predominance, with a female-to-male ratio of approximately 6: 1. It is a slow-growing tumor with a high rate of local recurrence. Because of its rarity, it is often initially misdiagnosed, frequently as a gynecological malignancy.

CASE REPORT: A 24 years old married primigravida female with 4 months amenorrhea presented to our tertiary care hospital with a large growth on the left labia majora since the age of 12 years. Initially the lesion was as small as a pea size and then gradually increased to a large cauliflower size. Her personal history included menarche at 15 yrs. of age with regular cycles. There was no h/o pain, swelling, bleeding or difficulty in carrying out daily routine activities. Patient denied any h/o similar lesions in the family.

Dermatological examination showed a large pedunculated polypoidal skin coloured growth approximately $12 \mathrm{cms} \times 15 \mathrm{cms}$ arising from left labia majora (photo: 1 ). The growth was soft in consistency.

The differential diagnosis considered was Giant achrochorodon and Plexiform neurofibroma.

The basic blood investigations were within normal limits. The patient was referred to gynaec deptt. and complete excision of the tumor was done.

Histopathology revealed many thick walled vessels of varying sizes in a loose myxoid and collagenous stroma with spindle and stellate shaped neoplastic cells (photo: 2).

Based on the clinical and histopathological examination a final diagnosis of angiomyxoma was made.

DISCUSSION: Angiomyxoma was 1st described by Steeper and Rosai in $1983 .{ }^{1}$

It mostly occurs in women of child bearing age and progresses rapidly during pregnancy suggesting estrogen may stimulate its growth. It has a peak incidence in the reproductive age group, although cases have been reported from 16 to 70 years. $^{2}$

It generally involves the genital, perineal, and pelvic region, with vulva being the most common site. Patients present with a painless, slowly growing soft tissue mass in the pelvi-perineal region, which may reach a large size by the time the patient seeks medical advice. 
Our case also had a similar course. A minority of cases have been reported in males, occurring in the scrotal, perineal, and inguinal regions. ${ }^{3}$ It may simulate inguinal hernia, testicular neoplasm, spermatic cord neoplasm, hydrocele, or spermatocele. ${ }^{4,5}$

This tumor arises from fibroblasts or myoblasts. Microscopically, the tumor is composed of spindle and stellate-shaped cells in a myxoid matrix. The tumor cells express vimentin, desmin, and smooth muscle antigen (SMA) and are negative for $\mathrm{S}-100 .^{3}$ Angiomyxoma is termed aggressive because of its propensity for local recurrences. ${ }^{4}$

Cytogenetic and molecular genetic analyses have revealed rearrangements of chromosomal region 12q13-15, resulting in altered expression of the HMGIC gene, a transcription factor belonging to the high mobility group of proteins. ${ }^{3}$

The differential diagnosis of aggressive angiomyxoma includes fibroepithelial stromal polyp, angiomyofibroblastoma, myxomas, superficial angiomyxoma, myxoid neurofibroma, myxoid liposarcoma, and myxofibrosarcoma. ${ }^{5}$ Superficial angiomyxoma differs clinically as they are superficially located and often polypoid. Histologically, they commonly involve the dermis and subcutaneous tissue, unlike AA, which is more deeply located.

Wide local excision is the therapy of choice. The excision of these tumors is difficult as they have the same consistency as that of normal connective tissue and therefore have a propensity for local recurrence.

Systemic metastases have been reported to occur. ${ }^{6}$ Long-term follow-up is necessary for early diagnosis of local recurrence and metastases. Imaging studies such as CT scan and MRI help in preoperative evaluation and postoperative follow-up as this tumor is ill defined clinically. ${ }^{7}$

A retrospective review has shown that patients having positive margins were as likely to have recurrence as those with negative margins. ${ }^{8}$

The presence of estrogen receptors in the tumor and its enlargement in pregnancy suggest the possibility of hormone dependence of this neoplasm. Gonadotropin-releasing hormone agonists have been suggested for those cases that are not amenable to surgical excision. ${ }^{8}$

A regular follow-up is important to evaluate local recurrence, if any.9, 10

\section{REFERENCES:}

1. Steeper TA, Rosai J. Aggressive angiomyxoma of the female pelvis and perineum: Report of nine cases of a distinctive type of gynecologic soft tissue neoplasm. Am J Surg Pathol 1983; 7: 463-75. [PUBMED].

2. Fetsch JF, Laskin WB, Lefkowitz M, Kindblom LG, Meis-Kindblom JM. Aggressive angiomyxoma-a clinico pathological study of 29 female patients. Cancer 1996; 78: 79-90. [PUBMED].

3. Graadt van Roggen JF, Hogendoorn PC, Fletcher CD. Myxoid tumours of soft tissue. Histopathology 1999; 35: 291-312. [PUBMED] [FULLTEXT]

4. Idrees MT, Hoch BL, Wang BY, Unger PD. Aggressive angiomyxoma of male genital region: report of 4 cases with immunohistochemical evaluation including hormone receptor status. Ann Diagn Pathol 2006. PubMed Abstract | Publisher Full Text

5. Tsang WY, Chan JK, Lee KC, Fisher C, Fletcher CD. Aggressive angiomyxoma: a report of four cases occurring in men. Am J SurgPathol 1992 16: 1059-1065. PubMed Abstract | Publisher Full Text. 


\section{CASE REPORT}

6. Blandamura S, Cruz J, Faure Vergara L, Machado Puerto I, Ninfo V. Aggressive angiomyxoma. a second case of metastasis with patient's death. Hum Pathol 2003; 34: 1072-4. [PUBMED]

7. Outwater EK, Marchetto BE, Wagner BJ, Siegelman ES. Aggressive angiomyxoma: Findings on CT and MR imaging. AJR Am J Roentgenol. 1999 Feb; 172(2): 435-8.

8. Mc Cluggage WG, Jamieson T, Dobbs SP, Grey A. Aggressive angiomyxoma of the vulva: Dramatic response to gonadotropin-releasing hormone agonist therapy. Gynecol Oncol 2006; 100: 623-5. [PUBMED] [FULLTEXT

9. Rai L, Nandyala V, Shetty J, Kumar V, Rao L. Aggressive angiomyxoma: An important differential diagnosis for a vaginal mass. Aust N Z J Obstet Gynaecol 2004; 44: 367[PUBMED][ FULLTEXT].

10. P Pahwa, BK Khaitan, A Rao, A Kriplani, R Mahey, KC Subbarao. Aggressive angiomyxoma of the vulva in a patient with systemic lupus erythematosus. IJDVL 2012; 78; 3; 361.

Photo 1: Pedunculated mass arising from labia majora.

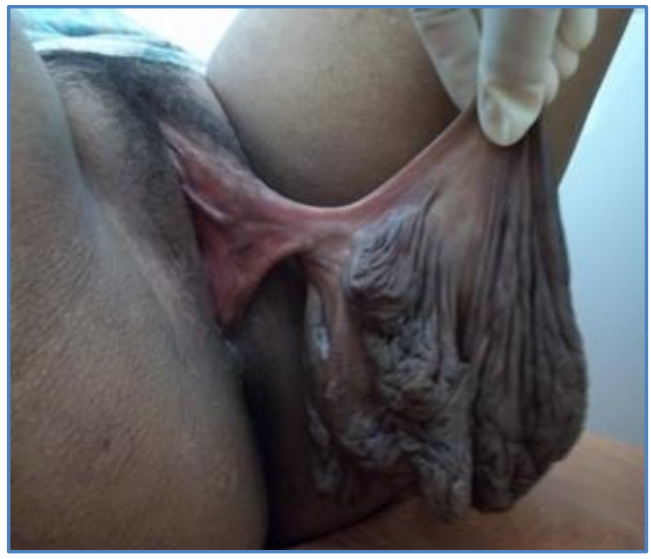

\section{Photo 1}

Photo 2: Histopathology: Thick walled vessels of varying sizes in a loose myxoid and Collagenous stroma with spindle and stellate shaped neoplastic cells.

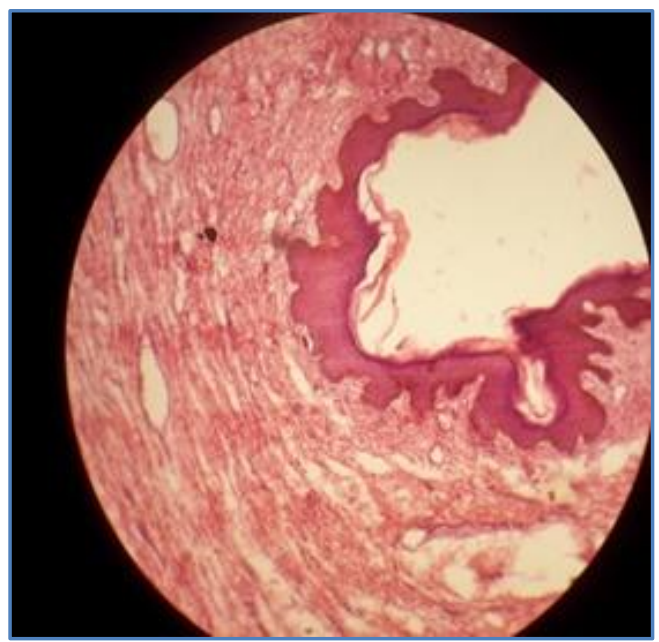

\section{Photo 2}




\section{CASE REPORT}

\section{AUTHORS:}

1. Ashok Jain

2. Anjali Dalai

\section{PARTICULARS OF CONTRIBUTORS:}

1. Professor, Department of Dermatology, Terna Medical College and Hospital, Nerul Navimumbai.

2. Lecturer, Department of Dermatology, Terna Medical College and Hospital, Nerul Navimumbai.

\section{NAME ADDRESS EMAIL ID OF THE} CORRESPONDING AUTHOR:

Dr. Ashok Jain, E34/04, Premsagar CHS,

Sector 29, Vashi, Navimumbai.

Email: dr_ashok71@yahoo.com

Date of Submission: 14/07/2014.

Date of Peer Review: 15/07/2014.

Date of Acceptance: 22/07/2014.

Date of Publishing: 31/07/2014. 